\title{
ON THE CLOSED-END FUNDS DISCOUNTS/PREMIUMS IN THE CONTEXT OF THE INVESTOR SENTIMENT THEORY.
}

\section{Ana Paula Carvalho do Monte}

Ad joint Prof. of Business Administration

Escola Superior de Tecnologia e de Gestão de Bragança

Campus de Santa Apolónia - Apartado 134

5301-857 Bragança

Portugal

Tel: $+351-273-30-3102$

Fax: +351-273-31-3051

apmonte@ipb.pt

and

Manuel José da Rocha Armada

Professor of Finance

Escola de Economia e Gestão - Universidade do Minho Gualtar 4710 BRAGA

PORTUGAL

TEL:+351-253-60-4555

FAX:+351-253-28-4729

rarmada@eeg.uminho.pt 


\title{
ON THE CLOSED-END FUNDS DISCOUNTS/PREMIUMS WHITHIN THE \\ CONTEXT OF THE INVESTOR SENTIMENT THEORY.
}

\begin{abstract}
The existence of closed-end funds discounts/premiums, although an issue largely studied, it is still puzzling both academics as well as practitioners. As it is well known, they result from the difference between the value of the shares of the fund, determined by the market, and their net asset value (the market value of the securities held by the fund, less the liabilities). Taking into account that the closed-end fund shares are traded on the stock exchange, as well as the assets included on their portfolios, no discrepancies would be expected (at least theoretically) between the market value of the funds and their net asset values, since the market should be able to adjust and correct the prices, due to the fact that the information is widely diffused.

In attempt to explain this "puzzle" several theories have been suggested. On one hand, those based on rational factors, such as: potential tax liabilities due to unrealised capital gains, the dividend policy, the fund portfolio composition, agency costs and management performance and, on the other hand, those based on behavioural factors, such as the investor sentiment theory. This latter framework, at least theoretically is, in our view, the one that seems to better explain almost all the features of the "puzzle", trying not only to explain the existence of discounts but also the existence of premiums and their behaviour among the funds themselves and over time.
\end{abstract}

In this context, we developed our research trying to explain the existence and persistence of the discounts/premiums. We also investigate the correlation between the discounts/premiums of those funds among themselves and each other over time, the mean reversion of the discounts/premiums, as well as the predictability power of the fund shares and of the net asset value returns. It was also our objective to search for the relevance of the investor sentiment theory in order to explain the discounts/premiums, so that we used Brauer's (1993) methodology and the signal extraction technique of French and Roll (1986). We also carried out (as far as we know, for the first time) a panel data analysis in order to check how much of the discounts/premiums variability is due to the presence of "noise traders".

This research was based on a sample of North-American closed-end funds, which invest mainly on stocks and/or bonds traded on the NYSE or on the AMEX, during the period from January 1987 to June 1999 (inclusive). The data was collected from the Wiesenberger database.

From the results that we got, we noticed that there seems to exist an indication of the presence of "noise traders" on the closed-end funds market which, in turn, seems to confirm the assumptions of the investor sentiment theory: the discounts/premiums were positively correlated, were mean reverted and had some predictability power in terms of fund share returns 
but not so much in relation to their net asset value returns. Nevertheless, we observed that the estimated proportion of the variance of standardised weekly discounts changes, explained by the investor sentiment on the total period studied, was only $8.6 \%$. Also, the results from the panel data analysis seem to suggest the relatively low importance of the investor sentiment theory to explain those discounts/premiums.

Key-words: Discounts/Premiums; Closed-end Funds; Investor Sentiment Theory; Behavioural Finance; Panel Data Analysis; Unit Root tests. 


\section{ON THE CLOSED-END FUNDS DISCOUNTS/PREMIUMS WHITHIN THE \\ CONTEXT OF THE INVESTOR SENTIMENT THEORY.}

\section{INTRODUCTION.}

As the price of the closed-end fund shares and its net asset value (NAV) are determined independently, they can diverge from each other and, as a consequence, we can observe either discounts or premiums, being the first ones the most common and persistent form, in recent years (v.g.: Dimson and Minio-Koserski; 1998; Elton, Gruber and Busse, 1998; Klibanoff, Lamont and Wizman, 1998). Nevertheless, taking into account that the closed-end fund shares are traded on the stock exchange, as well as the assets on their portfolios, no discrepancies would be expected (at least theoretically) between the market value of the funds and their net asset values. Besides the fact that the funds are frequently traded at discount, they vary from fund to fund, in the same period, and along the time. The flotation of the discounts follow, in general and closely, the market cycles and the launch of new funds happens in general during the phase in which the majority of the existing ones are at premium or at discount ${ }^{1}$. These new funds, usually, are placed in the market at premium but, surprisingly, this is going to be diluted, becoming at discount or at reduced premium (Lee, Shleifer \& Thaler, 1990).

Another intriguing aspect is the behaviour of the discounts when an open-ending operation is announced. In general, in such situation, it can be observed that the price of the fund tends to converge to its NAV, deeply reducing the discount. Afterwards, and until the operation effectively takes place, the discount still reduces, approaching zero, in most the cases ${ }^{2}$. We should point out, however, that the conflicts between the administration and the stockholders can obstruct and impede an open-ending operation (v.g.: Brauer, 1984; Barclay, Holderness \& Pontiff, 1993). In case the managers do not own significant participations in the fund, they will tend to resist to the operation because they can loose their jobs or certain privileges (for example: pecuniary benefits). The large stockholders, and the blockholders, can also resist, even if the operation can benefit them in terms of excess returns, because they may prefer to maintain their private benefits (v.g.: Barclay, Holderness \& Pontiff, 1993).

On the other hand, several authors (among others, for example: Cheng, Copeland e O'Hanlon, 1994; Pontiff, 1995; Arak e Taylor, 1996a; Sias, 1997b,) detected excess returns in relation to funds sold at high discount/premium as a result of implemented certain strategies having concluded that the discount/premium is mean reverting, at least in the short period. Given this apparent market inefficiency, it would be expected that the rational investors would try to take advantage of this opportunity and would implement arbitrage strategies. However, Pontiff (1995) concluded that those investors did not succeed to implement completely effective strategies. Consequently, the actual discount/premium of the fund containing information on the future discount/premium would also contain information which would allow forecasting fund returns (Pontiff, 1995; Cheung, Kwang \& Lee, 1997).

In attempt to explain the "puzzle" some theories were suggested. On one hand, perhaps the most common type of explanations, are those that are based upon rational factors, such as, the potential tax liabilities for the fund's unrealised capital gains, the dividend policy, the composition of the fund's portfolio, agency costs and management

\footnotetext{
${ }^{1}$ See for example Weiss, 1989 and Levis \& Thomas, 1995

${ }^{2}$ According to Brickley \& Schallheim (1985) the temporal pattern of the decline on the discounts is probably due to the reduction of the uncertainty about the effectiveness of the operation, i.e., if the fund will (or will not) be restructured.
} 
performance, among others. On the other hand, are those which are based upon behavioural factors like the investor sentiment theory.

The first set of theories tries to explain the existence of the discounts, but not always the premiums or of the behaviour of these at the time of an initial public offering (IPO) or of an open-ending operation. However, there are some factors, so called rational, which seem to have economic and statistical relevance for explaining the crosssectional behaviour of the discounts/premiums, such as the characteristics of the fund's portfolio composition (the existence of restricted assets, illiquid or foreign), the dividend policy, the unrealised capital appreciation, and agency costs.

The other set of theories, the investor sentiment theory (for example), seems to consider almost all the pieces of the "puzzle" trying, not only, to explain the existence of discounts but also of the premiums as well as their behaviour among funds and along time. Nevertheless, it is also not exempt of criticism, the main ones being related with the fact of being able to fully explain the variation of the discounts/premiums of the closed-end funds, an indicator of the investor's sentiment, and if this is (or not) a factor of systematic risk.

Within this context, we carried out our research trying to explain the existence and persistence of the discounts/premiums, having as starting point De Long, Shleifer, Summers \& Waldmann Model (1990). Having a deep relation with our main objective, we investigated the correlation among the discounts/premiums and of these for each fund over time, the existence (or not) of mean reversion for discounts/premiums as well as of their weekly changes, and also their predictive power on the fund's share returns as well as of their NAV returns. Finally, in order to investigate about the relevance of this theory for the explanation of the discounts/premiums, we applied the Brauer's (1993) methodology as well as the signal extraction technique of French and Roll (1986), carrying out also a panel data analysis (to the best of our knowledge for the first time) for checking how much of the variability of the discounts/premiums is due to the presence of noise traders.

This paper is structured in the following way: first we expose the investor sentiment theory and its applicableness to the closed-end funds, evidencing the implications of this in the behaviour and explanation of the discounts/premiums. After, we exhibit the methodology used to determine the relevance of this theory in the explanation of the variability of the discounts/premiums, as well as the several methods and statistical techniques such as the panel data analysis. On the fourth section, we describe the sample and define the variables used in the study. On the fifth section, we expose and analyse the results and, at last, we present the conclusions as well as some suggestions are indicated for future research.

\section{THE INVESTOR SENTIMENT THEORY AND ITS APLICABILITY TO THE CLOSED-END FUNDS.}

The investor sentiment theory is based on the notions of rational and informed investor versus non rational and less informed investor (the "noise traders") as well as the way that this latter type of investors affects the asset prices. De Long, Shleifer, Summers and Waldmann (1990) formalised such a theory, having presented a model of asset valuation upon these type of investors which do not act in a rational way, creating additional risk for the assets they hold.

According to these authors, there are two types of investors in the market: the rational investors and the noise traders. The first ones, which they designated by 
sophisticated investors $^{3}$, form their expectations based on information concerning the intrinsic value of the assets. They form rational expectations. The second ones, the noise traders, who do not have access to inside information, frequently form biased expectations about the asset prices. It can even be said that they act in an irrational way, as their expectations are not based on the assets' fundamental value but on the misleading information obtained from pseudo-signals of the market ${ }^{4}$. The optimistic or pessimistic noise traders' opinion makes the assets resale price become unexpected. As a result, the assets can be undervalued or overvalued. This unpredictability is worsened by the fact that the noise traders' opinion could change (or become even more extreme) during the period of the strategy implementation, creating an additional risk to rational investors ${ }^{5}$ - the "noise traders risk", which limit their performance as arbitrageurs. Consequently, asset prices can diverge significantly from their intrinsic values, albeit there is no fundamental risk (De Long, Shleifer, Summers \& Waldmann, 1990).

In this model, De Long, Shleifer, Summers \& Waldmann (1990) consider that the investors can invest in two asset types: assets without risk, that pay a real fixed dividend, $r$, which supply is perfectly elastic and risky assets which also pay a real fixed dividend, $r$, like the riskless assets but which supply is inelastic, i.e., the supplied quantity is fixed and normalised at one unit, that is why their price varies along time. According with the authors, the variation in the risky asset prices is mainly due to the misevaluation made by noise traders. So, the risky assets price is given, in equilibrium, by the equation:

$$
P_{t}=1+\frac{\mu\left(\rho_{t}-\bar{\rho}\right)}{1+r}+\frac{\mu \bar{\rho}}{r}-\frac{(2 \gamma) \mu^{2} \sigma_{\rho}^{2}}{r(1+r)^{2}}
$$

Where:

$P_{t} \equiv$ The price of the risky assets, in period $t$;

$r \equiv$ Fixed real dividend;

$\gamma \equiv$ Absolute coefficient of risk aversion;

$\mu \equiv$ Percentage of "noise traders" in the market;

$\rho_{l} \equiv$ non informed investor - "noise traders" sentiment, that is, their optimism or pessimism relatively to the asset prices, where: $\rho_{t} \sim N\left(\bar{\rho}, \sigma_{\rho}^{2}\right)$.

This equation represents the equilibrium risky assets price where the price depends on exogenous parameters of the model (the technological parameters, $r$, and the behavioural parameters, $\gamma$ ) plus the public information regarding the actual and future sentiment of the noise traders, i.e., the misperception (sentiment) about these asset prices by the noise traders, $\rho_{t}$, at moment $t$.

This model can be applied to the closed-end funds' pricing and it may explain the existence, variance and persistence of their discounts/premiums, if we consider that the closed-end fund's NAV is equivalent to the riskless asset of the model, since its fundamental value is easily calculated ${ }^{6}$, and the fund shares are equivalent to a risky asset. In this manner, the notion of noise traders can explain the "closed-end funds' puzzle" as the fund shares are subject to the "noise traders sentiment" which is

\footnotetext{
${ }^{3}$ These investors have access facilitated to all sources of information, including the inside information - private information, that is why their expectations are unbiased.

${ }^{4}$ These investors form their expectations on “(...) pseudo-signals from technical analysts, stockbrokers or economic consultants, and irrationally believe that these signals carry information" about the assets' intrinsic value (De Long, Shleifer, Summers \& Waldmann; 1990:706). For this reason, their expectations are biased and, in general, reflect their optimism or pessimism in relation to the asset prices.

5 These investors can select aggressive arbitrage strategies to explore the assets' mispricing but due to the noise traders' risk they are not able to drive asset prices to their fundamental values because, in general, they are risk averse.

${ }^{6}$ Closed-end funds pay a dividend equivalent to the sum of the dividends paid by the stocks in its portfolio; hence the market price of the fund should be equivalent to the sum of its portfolio market price.
} 
systematic and correlated among the funds ${ }^{7}$ (De Long, Shleifer, Summers \& Waldmann, 1990).

When investors are optimistic about closed-end funds, they force the fund prices to a superior level relative to its fundamental value, therefore the discounts decrease or become premiums. When the investors are pessimistic, the opposite is observed, discounts increase. Then, investors are subject to two types of risk: the risk from holding fund's portfolio (similar to the fundamental risk) and the risk of the resale price (equivalent to the "noise trader risk"). The resale price risk comes from the uncertainty in relation to the investor sentiment at the moment that they need to sell the fund, i. e., at that moment the discount might widen. If the sentiment is systematic, that is, if it affects all funds and other assets, then the associated risk should be rewarded. Due to this, closed-end funds have to sell, on average, at discount to reward the associated noise traders' risk (Lee, Shleifer \& Thaler, 1990; Shleifer \& Summers, 1990). Hence, closed-end funds sell, on average, at discount because discounts fluctuate and investors require an additional return for bearing the risk of fluctuating discounts (Shleifer \& Summers; 1990). Lee, Shleifer and Thaler (1991) point out that discounts/premiums changes reflect not the aggregated effect of investor sentiment change but the differential effect of the clientele that invest in closed-end funds relatively to the clientele that invest in the underlying assets of portfolio's funds ${ }^{8}$.

Lee, Shleifer \& Thaler (1991) call attention to a set of empirical implications for the pricing of closed-end funds as a consequence of the investor sentiment shifts as well. One of the implications is related by the fact discounts/premiums simultaneously vary across funds as it reflect widespread changes in investor sentiment. Hence, with reference to De Long, Shleifer, Summers \& Waldmann model (1990), theoretically, discounts/premiums changes have to be stochastic because, if discounts/premiums are constant, it would be quite easy to implement arbitrage strategies, even for short investment horizons and, therefore, discounts/premiums would decrease.

Another implication of this theory is regarding to new funds being placed in the market when the sentiment is positive (optimistic), that is, when the seasoned funds are traded at low discount or even at premium ${ }^{9}$.

In addition, the investor sentiment theory tries to explain why fund's price rises when an open-ending operation is announced and why discounts are reduced and afterwards eliminated when the open-ending operation happens ${ }^{10}$. As it is known that the fund will be reorganized or liquidated, investors can buy the fund shares and short sell the underlying assets (begin an arbitrage strategy to explore the remainder discount) because that strategy will be certainly lucrative, i.e., the risk of having to sell the fund while the discount is even widen no longer exists. The (small) discount that, eventually, still exists after the announcement of this operation, can be easily explained by the transaction costs of the arbitrage strategy ${ }^{11}$ or by some rational explanations of discounts/premiums (v.g. agency costs, tax liabilities on unrealised capital gains, among others), as is pointed out by Lee, Shleifer and Thaler (1991).

\footnotetext{
${ }^{7}$ The noise traders risk has to be systematic to be evaluated by them because the idiosyncratic risk, since it is diversifiable, it is not priced by the model.

${ }^{8}$ As De Long, Shleifer, Summers and Waldmann model require different clienteles, Lee, Shleifer and Thaler (1991) have assumed that noise traders probably invest more in closed-end funds than in its portfolio's underlying assets.

${ }^{9}$ Several empirical research papers corroborate this fact. See, for example, Weiss (1989), Peavy (1990), Levis and Thomas (1995), among others.

${ }^{10}$ This fact is supported by, among others, Brauer (1984; 1988), Hardouvelis, La Porta and Wizman (1993), Cheng, Copeland and O'Hanlon (1994), Pontiff (1995), Arak and Taylor (1996a; 1996b), Frankel and Schmuckler (1996), Sias (1997a) and, Cheung, Kwan and Lee (1997)

${ }^{11}$ An arbitrage strategy is never totally exempted of risk and costless (Lee, Shleifer \& Thaler, 1990).
} 
The majority of empirical research papers which intend to test this theory applied to closed-end funds discounts/premiums are based on De Long, Shleifer, Summers \& Waldmann model (1990), although, sometimes, they use different econometric methods to test its implications (v.g.: Lee, Shleifer \& Thaler,1990; Lee, Shleifer \& Thaler, 1991; Abraham, Elan \& Marcus, 1993; Brauer, 1993; Chen, Kan \& Miller, 1993; Chopra, Lee \& Shleifer,1993; Hardouvelis, La Porta \& Wizman, 1993; Bordutha, Kim \& Lee, 1995; Kramer \& Smith, 1995; Frankel \& Schmukler, 1996; Elton, Gruber \& Busse, 1998; Klibanoff, Lamont \& Wizman, 1998, among others). Notice, as well, that most of these papers are anchored in samples of "country funds". This may be due to the fact that these researches were done at the same time as the launch and development of this type of funds.

As far as we know, only Brauer (1993) attempted to measure the relevance of the investor sentiment theory concerning the explanation of the closed-end funds discounts/premiums variability, despite the critics that are done due to the use of "proxies" to identify the presence of noise traders in the market as given by the signal extraction technique of French and Roll (1986). Brown (1999) also tried to identify the presence of noise traders in the closed-end funds' market, but does not show a method to measure the relevance of this to the explanation of the existence and variability of the discounts/premiums.

\section{THE RELEVANCE OF THE INVESTOR SENTIMENT THEORY, APPLYING THE DEFINED METHODOLOGY FOR THE EFFECT.}

\subsection{The methodology of Brauer (1993).}

Brauer (1993) developed a methodology which intends to measure the relevance of the investor sentiment to the pricing of closed-end funds and to the explanation of its discounts/premiums variability. This is based on the De Long, Shleifer, Summers and Waldmann model (1990) and the signal extraction technique of French and Roll (1986).

Therefore, considering that the De Long, Shleifer, Summers \& Waldmann model (1990) implies that the price return of the closed-end funds shares is subject to an additional source of variation - the change in the noise traders sentiment about the fund price returns in relation to the returns of its portfolio's underlying assets, Brauer (1993) infer a model to predict the standardised variance of the discounts/premiums change in the closed-end funds over time ${ }^{12}$, that is given by the following expression:

$$
\operatorname{Var}\left(\Delta \tilde{D}_{t}\right) \cong \frac{\operatorname{Var}\left(\tilde{n}_{t}\right)}{\left[1+E\left(\tilde{r}_{P_{t}}\right)\right]^{2}}
$$

In that:

$$
\begin{aligned}
& \operatorname{Var}\left(\Delta \tilde{D}_{t}\right) \equiv \text { Estimated variance of standardised discounts/premiums change, over time. } \\
& \operatorname{Var}\left(\tilde{n}_{t}\right) \equiv \text { Variance of the price return of the fund shares due to "noise trading". } \\
& E\left(\tilde{r}_{P_{t}}\right) \equiv \text { Expected value of NAV returns. }
\end{aligned}
$$

Where the standardised discounts/premiums change over time (a random variable) is given by the expression:

$$
\Delta \tilde{D}_{t}=\frac{\Delta \tilde{d}_{t}}{d_{t-1}+1}
$$

As:

\footnotetext{
${ }^{12}$ To verify the demonstration of this deduction consult Monte (2000) and Brauer (1993).
} 
$\begin{aligned} \Delta \tilde{d}_{t} & \equiv \text { Discounts/premiums change of the period } t-1 \text { for the period } t \text { (random variable) } \\ d_{t-1} & \equiv \text { Discount/premium of the period. }\end{aligned}$

The expression (2) is the operational form of the De Long, Shleifer, Summers and Waldmann model (1990) prediction about the variance of discounts changes over time. According to Brauer (1993) the assessment of this approach requires the estimate of two statistics $E\left(\widetilde{r}_{P_{t}}\right)$ and $\operatorname{Var}\left(\widetilde{n}_{t}\right)$, for a closed-end fund. Assuming that the fund's NAV is random walk, i.e., it is identical and independently distributed (i.i.d.), then $E\left(\widetilde{r}_{P_{t}}\right)$ can be estimated by the mean weekly rate of return on the fund's portfolio, which is represented by $\bar{r}_{P_{t}}$. The estimate of $\operatorname{Var}\left(\tilde{n}_{t}\right)$, the variance of the rate of return of the fund's stocks price due to noise trading, can be achieved, according to the author, through the signal extraction technique used by French and Roll (1986).

According to French and Roll (1986), long term returns are less affected by the noise traders sentiment than short term returns because the misevaluation induced by the noise traders activity tends to revert (it is mean reverting) sooner or later. So, if daily returns are independent, the returns for longer holding periods should be equal to the accumulated daily returns within that period. But if daily returns are correlated to each other and across time ${ }^{13}$ due to noise traders' activity, subsequently the longer holding periods' variance will be smaller than the variance of cumulated daily returns (French \& Roll; 1986).

The French and Roll signal extraction technique ${ }^{14}$ that intend to, specifically, identify the fraction of the daily return variance caused by the information, which they represent as $V_{6}$, consists in several steps. First, compute the average daily rate of return for each subperiod of two years of the sample (the authors use a total period of twenty years). The second step comprises the sum of the squared deviations around that average. After, under the assumption that the daily returns are serially independent, estimate the implied six-month variance by dividing the sum of the squared deviations by four, since each two year subperiod contains four semesters. Finally, divide the actual variance of six-month return for the subperiod by the implied variance. In order to measure how much the daily return is affected by noise, the assumption of the serial independence will be violated by the presence of negative autocorrelation and the observed six-month variance will be smaller than the cumulated daily variance (Brauer; 1993). French and Roll (1986) determine the lower and upper bound of the relative variance error. The upper bound ${ }^{15}$ is given by the difference between one and the ratio of six-month variance ${ }^{16}$ (the ratio between the variance of the daily information component and the total daily return variance). The lower bound ${ }^{17}$ is given by a third of the difference between one and the ratio of the six-month variance plus two thirds of the first order autocorrelation of the daily return.

When, Brauer (1993), applied this methodology to variance of the discounts/premiums change of the closed-end funds using weekly rates of return of the funds and considering the ratio of the actual-implied six-month variance as representative of the fraction of the weekly return variance due to the incorporation of

\footnotetext{
${ }^{13}$ If there is positive autocorrelation among daily returns, then it is not, obviously, independent.

${ }^{14}$ French and Roll (1986) analysed three possible theories to explain the variance of the daily rate of return of the assets, during normal business hours and out of this schedule: the theory of information, the theory of noise trading and the theory of bid-ask spread. These theories are not mutually exclusive; they could explain together the daily asset prices volatility (French \& Roll, 1986).

${ }^{15}$ Assuming that the variance of bid-ask spread error is null (French \& Roll; 1986).

${ }^{16}$ Represent as $\mathrm{V}_{6}$, as we have already mentioned.

${ }^{17}$ Assuming that the daily return components are serially independent (French \& Roll; 1986).
} 
the information, having represented it as $V_{6}^{*}$. Taking into account that, the De Long, Shleifer, Summers and Waldmann model (1990) claims that $\tilde{r}_{S t}=\tilde{r}_{P t}+\tilde{n}_{t}$, where $\tilde{r}_{S t}$ is the weekly return of the fund shares prices, as a result, according to Brauer (1993), $\left[\left(1-V_{6}^{*}\right) \operatorname{Var}\left(\tilde{r}_{S_{t}}\right)\right]$ represents an estimate of $\operatorname{Var}\left(\tilde{n}_{t}\right)$ for the weekly return. Thus, considering equation (2), the estimated variance of the discounts/premiums change is given by:

$$
\operatorname{Var}\left(\Delta \tilde{D}_{t}\right) \cong \frac{\left(1-V_{6}^{*}\right)}{\left(1+\bar{r}_{P_{t}}\right)^{2}} \operatorname{Var}\left(\tilde{r}_{S_{t}}\right)
$$

\subsection{Additional delineation of the research.}

Bearing our objective in mind, we will try to explain the existence and persistence of the discounts/premiums in the context of the investor sentiment theory, testing some of its implications in the behaviour of closed-end fund discounts/premiums (namely: the correlation among the discounts/premiums across funds and along time, the discounts/premiums and its weekly change mean reversion, as well as its predictive power on the fund share price return and its NAV). It is also our goal to investigate about the relevance of the investor sentiment theory for the explanation of the discounts/premiums variability.

Thus, we design our research in two phases. In the first phase, we start by determining the correlation of the weekly discounts/premiums levels across the funds in the sample, the correlation of the weekly discounts/premiums changes, applying the Pearson correlation coefficient, attempting to test whether the discounts/premiums are positively correlated. Next, we analyse the behaviour of the time series of the discounts/premiums levels and its weekly changes to confirm if these are stationary. For this purpose, we will carry out the classic tests of unit root, i.e., the stationarity tests: Augmented Dickey-Fuller Test and Phillips-Perron Test on these variables. The number of lags is determined by Akaike Information Criterion (AIC). Finally, in order to test the predictive power of the discounts/premiums ${ }^{18}$ we consider the relationship between the cumulated share price return of the funds and discounts/premiums, as well as the cumulated NAV return of the funds and its discounts/premiums, through the following regressions:

$$
\begin{aligned}
& \sum_{k=1}^{K} R F N D_{i, t-k}=\alpha_{i, t}^{f}+\beta_{i, t}^{f} D I S C_{i, t}+e_{i, t}^{f} \\
& \sum_{k=1}^{K} R V P L_{i, t-k}=\alpha_{i, t}^{v}+\beta_{i, t}^{v} D I S C_{i, t}+e_{i, t}^{v}
\end{aligned}
$$

Where:

$$
\begin{aligned}
& \sum_{k=1}^{K} R F N D_{i, t-k} \equiv \text { The cumulated share price returns of the fund } i \\
& \sum_{k=1}^{K} R V P L_{i, t-k} \equiv \text { The cumulated NAV returns of the fund } i \\
& D I S C_{i, t} \equiv \text { The discount/premium of the fund } i \text {, in the period } t ; \\
& \alpha_{i} \text { e } \beta_{i} \equiv \text { The fund-specific intercept and slope coefficients, respectively. } \\
& K \equiv \text { The cumulative return horizon of investment (as suggested by Hardouvelis, La Porta and } \\
& \text { Wizman, 1993, horizons of one, four and thirteen weeks are used). }
\end{aligned}
$$

\footnotetext{
${ }^{18}$ Considering that the investor sentiment theory also claims that discounts/premiums contain information concerning future returns.
} 
To correct the heteroskedasticity problem we use the method of White (1980) for one week investment horizon of return, and the method of Newey-West (1987), for investment horizons of four and thirteen weeks ${ }^{19}$.

Regarding the underlying advantages of using panel data analysis, in particular to this type of surveys (despite its limitations ${ }^{20}$ ), which characterise the phenomenon considering its individual and time-series characteristics, we test as well the predictive power of the discounts/premiums on the fund returns and NAV returns using this technique, as far as we know for the first time in this type of research. We achieve the following procedures: test the homogeneity of the coefficients - to test whether the parameters of the model are homogeneous (across individuals and through the time), covariance analysis and model of error component is used - to test the heterogeneity of the interception and homogeneity of the slope. If it is not rejected, it is still applied the conditional test of the interception homogeneity as the slope is homogeneous, i.e., the Hausman $^{21}$ test is applied to determine if we should use the fixed effects model or the random effects model.

After having tested these implications of the investor sentiment theory in the behaviour of closed-end funds discounts/premiums (and of its changes), we pass to the second phase of the research where we investigate on the relevance of this theory in the explanation of the discounts/premiums variability. Consequently we apply the methodology of Brauer (1993) and the signal extraction technique of French and Roll (1986), as follows:

1st step - Calculate the standardised weekly discounts/premiums changes, considering the expression (3), and compute its descriptive statistics as mean, standard deviation, skewness, kurtosis, autocorrelation with lags of one, two, three and four weeks and the standard error of the 1st order autocorrelation.

2nd step - Determine the mean weekly fund price returns for each two years subperiod of the twelve years sample total period (which represent six subperiods in the total) and the sum of the square deviations around each mean, in each subperiod and for each fund.

3rd step - Estimate the implied six-month variance by dividing the sum of the square deviations by four ${ }^{22}$.

4th step - Compute the actual - implied six-month variance ratio through the division of the actual (observed) six-month variance by the implied six-month variance, as calculated in the previous step.

5th step - Calculate the "great mean" by averaging the actual - implied variance ratio among all the funds, in each period, and divide this by the total number of subperiods (average for period of the implied variance average ratio for fund).

6th step - Compute the estimated standardised weekly discounts/premiums changes variance, regarding expression (4), as $V_{6}^{*}$ represents the "great mean", calculated in the previous step; $\bar{r}_{P_{t}}$ is the weekly mean fund NAV return in the subperiod or period and $\operatorname{Var}\left(\widetilde{r}_{S_{t}}\right)$ is the variance of the fund shares price return (trade-to-trade) in the subperiod or period.

7th step - Calculate the estimated proportion of the standardised weekly discounts/premiums changes variance explained by the presence of noise traders (and,

\footnotetext{
${ }^{19}$ These methods can be automatically applied when the univariate regression is considered by the least square method, using the statistical package EViews. The method of White (1980) presupposes that the residuals of the estimated equation are serially uncorrelated, while Newey-West method (1987) proposes a covariance matrix estimator that is consistent with the presence of both heteroskedasticity and autocorrelation of unknown form. For investment horizons of one period, these methods are identical.

${ }^{20}$ About this subject sees, for example, Jorge (1997), Baltagi (1995), Hsiao (1986) and Hausman and Taylor (1981).

${ }^{21}$ See, v.g.: Hausman, 1978; Hausman and Taylor, 1981; Holly, 1982; Hsiao, 1986; Arellano, 1993 and Baltagi, 1995.

${ }^{22}$ This is the number of semesters in the two years subperiod.
} 
consequently, for the investor sentiment theory), dividing the estimated variance (calculated in the previous step) by the observed standardised weekly discounts/premiums changes variance in the sample subperiod or period.

To test the robustness of the results, we analyse the relationship between the observed and estimated variance of standardised weekly discounts/premiums changes as well as the relationship between the observed variance of the standardised weekly discounts/premiums changes and the specific-value of $\left(1-V_{6}^{*}\right)$ for each fund ${ }^{23}$. The generic linear regression models are, respectively:

$$
\begin{aligned}
& \operatorname{Var}\left(\Delta \tilde{D}_{t}\right)_{\mathrm{i}, \mathrm{t}}=\phi_{0 \mathrm{i}, \mathrm{t}}+\phi_{1 \mathrm{i}, \mathrm{t}} \operatorname{Var}\left(\Delta D_{t}\right)_{i, t}+\varepsilon_{i, t} \\
& \operatorname{Var}\left(\Delta \tilde{D}_{t}\right)_{1, \mathrm{t}}=\varphi_{0 \mathrm{i}, \mathrm{t}}+\varphi_{1 \mathrm{i}, \mathrm{t}}\left(1-V_{6}^{*}\right)_{i, t}+\varepsilon_{i, t}
\end{aligned}
$$

Where:

$$
\begin{aligned}
& \operatorname{Var}\left(\Delta \tilde{D}_{t}\right)_{1, \mathrm{t}} \equiv \text { Actual variance of the standardised weekly discounts/premiums changes; } \\
& \operatorname{Var}\left(\Delta D_{t}\right)_{i, t} \equiv \text { Estimated variance of the standardised weekly discounts/premiums changes; } \\
& \left(1-V_{6}^{*}\right)_{i, t} \equiv \text { Proportion of the variance of the shares price return of the fund attributed to the noise } \\
& \quad \text { trading, specific to each fund; } \\
& \phi_{0 \mathrm{i}, \mathrm{t}} ; \phi_{1 \mathrm{i}, \mathrm{t}} \mathrm{e} \varphi_{0 \mathrm{i}, \mathrm{t}} ; \varphi_{1 \mathrm{i}, \mathrm{t}} \equiv \text { Linear regression coefficients; } \\
& \varepsilon_{i, t} \equiv \text { Random error. }
\end{aligned}
$$

We use panel data analysis to improve the resulting information of these linear regressions (as best of our knowledge for the first time for this effect).

\section{DESCRIPTION OF THE SAMPLE AND DEFINITION OF THE VARIABLES.}

The data was obtained from Wiesenberger closed-end funds database, which we selected a sample of 41 closed-end investment funds traded in the New York Stock Exchange (NYSE) and/or in the American Stock Exchange (AMEX), that invest mainly in North American, specialised or diversified stocks and/or bonds - excluding the "country funds" and the "municipal bonds funds", during the period of January 2, 1987 to June 18, 1999 (inclusive), with a minimum of 104 observations. The fund to be included should have a report of, at least, two years of publication either of its quotations (price of the fund) or of its NAV. Nonetheless, it is not a primordial feature for this research, as we have no intention of evaluating the performance of these funds, the selected sample does not suffer of the survivorship bias problem because the sample has funds that stopped existing during the sample period and others that started in the meantime.

On table 1, in the appendix, we list the funds contained in the sample. With reference to the empirical research done by other authors, namely Brauer (1984) and Peavy (1990), we made two adjustments in the time-series of the sample. Hence, the first 24 observations were not considered (equivalent to six months) after the date of IPO of the fund because, as Peavy (1990) claims, discounts tend to increase in the weeks after the fund IPO which could cause a bias in the results. On the other hand, we did not include those observations of the six months previous to the open-ending operation date because discounts tend to decrease during the period previous to the open-ending operation announcement, as supported by Brauer (1984) research ${ }^{24}$. The

\footnotetext{
${ }^{23}$ This value represents the proportion of the fund shares return variance due to the noise trading (as it was estimated by the signal extraction technique of French and Roll, 1986), i.e., the portion of the variance that is not attributable to the information.

${ }^{24}$ Thus, some funds lost some observations due to these adjustments.
} 
number of observations on table 1 , in the appendix, is relative to the effective number of observations, previously corrected by these adjustments.

The variables in study are defined like this:

$R F N D_{t} \quad$ - The price return of the fund shares, in continuous capitalisation that is calculated as: $R F N D_{t}=\ln \left[P_{t}+D_{t}\right]-\ln \left[P_{t-1}\right]$

Where:

$P_{t} \equiv$ Fund Price, at the end of the week $t$, (closing price);

$D_{t} \equiv$ Total dividend distributed by the fund at the end of the week $t$ (= distribution of income and capital gains);

$R V P L_{t}-\mathrm{NAV}$ returns of the fund, in continuous capitalisation, specified as: $R V P L_{t}=\ln \left[V_{t}+D_{t}\right]-\ln \left[V_{t-1}\right]$

Where:

$V_{t} \equiv$ Net asset value, at the end of the week $t$;

$D_{t} \equiv$ Total dividend distributed by the assets that composes the fund portfolio, at the end of the week $t$.

The cumulated return, for four and thirteen weeks, either for fund return or its net asset value, is calculated by the sum of the weekly return to the proposed cumulated investment horizon.

$D I S C_{t}$ - Discount/premium, in percentage: $\quad D_{I S C_{t}}=\frac{P_{t}-V_{t}}{V_{t}} \times 100$

$\Delta D I S C_{i, t+1}-$ Discount/premium change, which is given as: $\Delta D I S C_{l, l}=D I S C_{, l}-D I S C_{, t-1}$

Although we do not plan to analyse the results in this section, we think that is important to emphasize (see table 2, in the appendix) that discounts/premiums vary over this period. The higher mean discount was at $1988(-8.45 \%)$ and the higher premium in $1992(0.44 \%)$.

\section{THE RESULTS AND THEIR ANALYSIS.}

\subsection{The discounts/premiums correlation.}

One of the assumptions of the investor sentiment theory, applied to the closed-end funds discounts/premiums, claims that discounts/premiums are positively correlated among them (Lee, Shleifer \& Thaler, 1990). Therefore, we test the null hypothesis that the closed-end funds discounts/premiums are not correlated, using the Pearson coefficient of determination.

We have confirmed that more than half $(71 \%)$ of the correlation coefficients are positive (see table 3, in the appendix), and about $88 \%$ of these are statistically significant. As a consequence, this is suggestive that the closed-end funds discounts/premiums are correlated to each other and they tend to move together. The same result is found in relation to the weekly discounts/premiums change $\mathrm{e}^{25}$.

These results are consistent with the results of Lee, Shleifer and Thaler (1991) as well as Cheung, Kwan and Lee (1997). Since these results seem to confirm one of the implications of the investor sentiment theory which predicts that closed-end funds discounts/premiums (and discounts/premiums change) are driven by the investor sentiment, and so they are likely to vary together.

\subsection{The stationarity of the discounts/premiums.}

${ }^{25}$ The results of these tests can be requested to the authors. 
The stationarity analysis becomes important because if the discounts/premiums reflect the investor sentiment, since, concerning the investor sentiment theory, the sentiment is mean reverting, then the discounts/premiums should be mean reverting as well. The hypothesis of unit root of the discounts/premiums level as well as weekly discounts/premiums change is tested applying the classic tests of Augmented DickeyFuller (ADF) and Phillips-Perron (PP) test ${ }^{26}$, integrated in the EViews package ${ }^{27}$.

By ADF test (see table 4, in the appendix), at a significance level of $5 \%$ or $10 \%$, it is not possible to conclude whether the discounts/premiums tend to be stationary or not. By PP test, at a significance level of $5 \%$, or even $10 \%$, the hypothesis that the proportion of funds with non stationary discount/premium is $50 \%$ is rejected, which shows that discounts/premiums seems to be stationary.

It is even found that the series of the weekly discounts/premiums change are stationary for most of the funds ${ }^{28}$.

\subsection{The predictive power of the discounts/premiums on the net asset value return and of the share price return of the funds.}

The discounts/premiums mean reversion implies that the actual discount/premium should contain information on future discount/premium and, consequently, we can estimate future returns. As the discounts/premiums change reflect, roughly, the difference between the funds return and its underlying assets returns ${ }^{29}$, the discounts/premiums will be correlated whether with the fund share price returns (hereafter fund return, for simplicity), or with its NAV return.

To study the discounts/premiums predictive power on future fund return as well as of its NAV, we used panel data analysis and we have computed cumulated returns for investment horizons of one, four and thirteen weeks, as it is suggested by Hardouvelis, LaPorta and Wizman (1993:18). So, as to test the homogeneity of the regression coefficients, we estimated regressions (5) and (6), as defined in the section 3.2, resulting from there the appropriate Covariance Model.

Analysing table 5, in the appendix, it is shown that, in most cases, and for any investment horizon $(\mathrm{K})$, closed-end funds discounts/premiums are positively correlated with fund return, that is, an increase in the discount/premium level compel to a consequent increase in the fund return. As $\mathrm{K}$ enlarges, $\beta_{i}^{f}$ increases, this is statistically significant for more than $50 \%$ of the funds, at a significance level of $5 \%$.

These results corroborate other empirical research on this subject (v.g.: Hardouvelis, LaPorta \& Wizman, 1993: 19) and imply that closed-end funds discounts/premiums might predict fund returns, as investor sentiment is a component of the fund price, corroborating the hypothesis that discounts/premiums are positively correlated with the fund return.

The discounts/premiums have less predictive power on NAV returns. Although, the majority of the closed-end funds discounts/premiums are negatively correlated with the cumulated NAV return (see table 6, in the appendix), only some funds present

\footnotetext{
${ }^{26}$ Once the graphic representation of the series of the variable discounts level was not very clear with relationship to its behaviour and as no economics reasons seems to exist that justify the inclusion of the tendency in the closed-end funds, we had just considered the test regression with constant.

${ }^{27}$ The ADF test is not very powerful, as Stwart and Gill (1998:239) as well as Pindyck and Rubinfeld (1998:51) say, that is why its capacity to detect the absence of unit roots, when it does not exist, is reduced. It just allows us to reject the hypothesis that the variable is not random walk.

${ }^{28}$ In the stationarity analysis, we have applied, in the same way, the two classic tests, the ADF test and PP test whose results can be requested to the authors.

${ }^{29}$ Mainly if we consider that the distribution of dividends is not very significant.
} 
$\beta_{i}^{v}$ negative and statistically significant, as a consequence, occasionally, closed-end funds discounts/premiums contain information on the future NAV return.

The fact that discounts/premiums have some predictive power on fund return but less obvious on NAV return can be justified, in part, by the difference of clienteles that invest in the closed-end funds and in its underlying assets. The majority of closed-end funds are traded by small investors - noise traders - while funds' underlying assets can be traded by institutional investors (more informed and that act in a more "rational way"), reducing the weight of the noise traders on these assets (Lee, Shleifer \& Thaler, 1991). Accordingly, the influence of the noise traders on the fund's portfolio price is less significant, in that case the discounts/premiums have little predictive power on the NAV return.

Next, we impose the condition of total homogeneity of the coefficients (whether of the interception or the slope). Those regressions constitute the Simple Model. This hypothesis is rejected, at any significance level and investment horizon considered - see table 7, in the appendix. So, we try to investigate if the heterogeneity of the coefficients can be attributed to the slope or to the interception, testing the hypothesis $\mathrm{H}_{2}$ : the homogeneity of the slope and the heterogeneity of the interception (the slope is common but the interception is variable). Therefore, we estimate the Intra-individuals Model. As it is shown on table 7 , in the appendix, the $\mathrm{F}_{2}$ test is not significant which is not possible to reject $H_{2}$. Then, we want to know if the heterogeneity is coming of the interception, testing $\mathrm{H}_{3}$ : the interception is homogeneous as the slope. At any significance level, $\mathrm{H}_{3}$ is rejected, as a consequence, the interception is heterogeneous even the slope is homogeneous (see table 7, in the appendix).

In this manner, we should use the fixed effects model as regression model to represent the predictive power of the discounts/premiums on the cumulated fund return as well as its NAV returns (see table 8 , in the appendix). Those models show that discounts/premiums have some predictive power on the (future) funds return as well as on its NAV return given that the slope is statistically significant in both cases.

\subsection{The investor sentiment theory as explanatory factor of the discounts/premiums variance.}

After having tested some of the implications of the investor sentiment theory, namely, the positive correlation among the discounts/premiums (the discounts/premiums covariance), the discounts/premiums stationarity and the discounts/premiums predictive power on fund return or on NAV return, it is intended to test now the relevance of this theory in the explanation of the existence and persistence of the discounts/premiums, assuming that it explains a part of the discounts/premiums variance.

For this study, we the analysed period from $2 / 01 / 1987$ to $31 / 12 / 1998$ and we only included funds in which the difference between the number of observations of the time series of the fund return and the ones of the net asset value return is less than $1 \%$ of the total observations. So, we eliminated in these series the observations that are not synchronized $^{30}$. We impose these limitations since the Brauer (1993) methodology as well as the French and Roll (1986) technique imply that identical number of observations is used in the fund return as of NAV return.

Considering the expression (3), the standardised discounts/premiums change is computed and its mean, standard deviation, skewness, kurtosis, autocorrelation with

\footnotetext{
${ }^{30}$ As a result, the following funds are eliminated from the initial sample of 41 funds: ALM, CET, CIM, CNN, CTF, EGX, EIS, FT, HU, IIS, JHI, MRF, PEO, RIF and VIN.
} 
lags of one, two, three and four weeks as well as the standard error of the 1st order autocorrelation $^{31}$ are calculated. Notice that all funds of the sample have negatives $1 \mathrm{st}$ order autocorrelation coefficients ${ }^{32}$, which is consistent with the results of Brauer (1993) and Bonser-Neal, Brauer, Neal and Wheatley (1990). According to these authors, given a negative 1st order autocorrelation coefficient of weekly discounts/premiums change this is an indicator of the presence of noise traders, like French and Roll $(1986 ; 15)$ say $^{33}$.

Afterwards, we calculate the "great mean" $-V_{6}^{*}$, which result was of 0.929 , what means that, according to the signal extraction technique of French and Roll, $92.9 \%$ of the closed-end fund shares rate of return variance is due to the rational answer of the investors to the information emitted for the market and $7.1 \%$ of that variance is just due to the noise. For this reason, a small portion of the fund shares variance can just be explained by the investors' irrational behaviour and, as consequence, investor sentiment is likely to have low significant weight in the mispricing of the assets. Our results are slightly superior to the Brauer (1993) results which was $V_{6}^{*}=0.947$ and the portion of the return variance explained by the noise of $5.3 \%$.

At last, we calculate the estimated - observed weekly standardised discounts/premiums change variance ratio. The estimated weekly standardised discounts/premiums change variance is calculated by the expression (4), having used the ratio between the weekly mean fund NAV return and the fund shares return variance. These results are summarised on table 11, in the appendix. The first value of this table corresponds to the estimated variance in relation to observed weekly standardised discounts/premiums change variance ratio. The second value corresponds to the number of observations used in the calculation of the previous ratio, for each fund and in each period. The last two lines of this table correspond, respectively, to the weighed average of the estimated to observed variance ratio, weighed by the number of observations in each period, for all the funds and to the number of total observations of the period.

Taking the last value of the ratio on table 11, in the appendix, corresponding to the total period analysed, the percentage of the observed weekly standardised discounts/premiums change variance over time, explained by the investor sentiment theory, for all the funds in the sample is, around, $8.55 \%$, slightly superior to the $6.77 \%$ achieved by Brauer (1993:211).

Dividing the total period in study in three subperiods (1987 to 1990; from 1991 to 1994 and from 1995 to 1998), the period from 1987 to 1990 was the one that showed the largest percentage $(9.65 \%$, approximately) of the observed weekly standardised discounts/premiums change variance, explained by the investor sentiment theory. Analysing fund to fund, it is shown that the model can explain, in the best of hypotheses, about $12 \%$ of the weekly standardised discounts/premiums change variance of the funds $\mathrm{ADX}, \mathrm{GAB}, \mathrm{SBF}$ and TY. The remaining funds present equal or lower percentages than $11.5 \%$, having found the smallest percentage in the case of the fund BKT (5.69\%), in the period from 1987 to 1998. Analysing by subperiod, and across

\footnotetext{
${ }^{31}$ These results can be obtained directly by the authors.

32 According to Brauer (1993) and Bonser-Neal, Brauer, Neal and Wheatley (1990), the negative 1st order autocorrelation in the weekly the discounts/premiums is due to the nonsynchronous trading between fund stocks and their respective underlying assets, above all to the smallest trade frequency of the closed-end funds stocks.

${ }^{33}$ In agreement with the investor sentiment theory (under the hypothesis of presence of noise traders), fund shares returns should be autocorrelated, while its pricing errors would be corrected in long run, as these corrections would generate negative autocorrelations (French \& Roll, 1986:15). On the other hand, according to these authors, due to the fact that each closing trade may be executed at any price within the bid/ask spread, the negative 1st order autocorrelation can be induced by this type of mispricing, mainly if these measurement errors are independent from day to day.
} 
funds, it is realised that the model allows the explaination, at the most, around $15 \%$ of the weekly standardised discounts/premiums change variance of the fund $G A B$, in 1987-90. But in the period of 1991-94, the highest percentage that the model can explain is only $10.8 \%$, approximately (for the case of the fund TY).

These results suggest that, although the presence of noise traders in the closed-end funds sector can influence and justify the discounts/premiums existence, no more than $9 \%$, roughly, of the variance of the discounts/premiums changes would be explained by presence of noise traders. Like Brauer (1993), we can not confirm that the investor sentiment has a lot of relevance on the explanation of the discounts/premiums variability.

Using the panel of the observations connected with the 26 funds in the sample, during the three subperiods in that the time horizon was distributed (1987-90; 1991-94 and 1995-98), we test the robustness of our results. Consequently, we analyse the relationship between the observed standardised discounts/premiums weekly change variance and the estimated one, set out of the generic linear regression model (7) as defined in the section 3.2. Based on the generic linear regression model (8), we analyse the relationship between the standardised discounts/premiums weekly change variance (observed) and the specific value of each fund $\left(1-V_{6}^{*}\right)$ - the portion of the fund return variance that is not caused by the information.

In first place, we have estimated the simple linear regression model, i.e., that with both homogeneous coefficients (whether the interception or the slope are not variable with the time and of fund to fund). After that, we have estimated the specific linear regressions to each fund, which constitute the covariance model ${ }^{34}$.

Taking the sum of the squares of the residuals of each model, we have tested $H_{1}$ : total homogeneity of the coefficients. Consistent with the statistics of $F_{1}$ test, in both situations, we reject the null hypothesis since $F_{1}$ is significant, at a significance level of at least $1.5 \%$ - see table 9, in the appendix. Hence, we have tested the hypothesis $\mathrm{H}_{2}$ : homogeneity of the slope and heterogeneity of the interception. Therefore, we have considered the fixed effects model. The results of the $\mathrm{F}_{2}$ test do not allow us, in both situations, to reject the null hypothesis $\mathrm{H}_{2}$. Like so, we carry out the conditional test of hypothesis $\mathrm{H}_{3}$ : interception homogeneity given the homogeneity of the slope. In this case, for the first situation, the hypothesis is rejected, at a significance level of fence $3.5 \%$, and for the second situation the hypothesis is not rejected, at a significance level of at least $10 \%$.

Thus, the model of fixed effects, according to the results of the tests, is the most suitable to specify the relationship between the observed weekly standardised discounts/premiums change variance and the estimated one - see table 10, in the appendix. The pooled regression or the simple model is, in accordance with the results of the tests, the most suitable to specify the relationship between the observed weekly standardised discounts/premiums change variance and the specific value of each fund (1 - $V_{6}^{*}$ ) - see table 10 , in the appendix.

Analysing the relationship between the observed weekly standardised discounts/premiums change variance and the estimated one, the results suggest that, on average, funds with larger estimated standardised discounts/premiums weekly change variance might have larger observed variance. This correlation is statistically significant. The high $\mathrm{R}_{2}$ (determination coefficient), in addition to the significant coefficient, suggest that the ratio between both variances tends to be quite stable from

${ }^{34}$ These procedures were followed in the two situations in study. 
fund to fund and over the time. Only about $9.1 \%$ of the observed variance is not explained by the implied variance ${ }^{35}$. Even the high coefficient of determination, we cannot infer that noise trading explains a substantial portion of the weekly standardised discounts/premiums change variance of the funds. Considering that the approximate expression (4) is used to determine the estimated weekly standardised discounts/premiums change variance and we use the same value $V_{6}^{*}$ for all funds, these results reflect strong correlation between the observed weekly standardised discounts/premiums change variance and the variance of the fund weekly return, which suggest that funds with more volatile share prices also have larger discounts/premiums variability.

In relation to the second relationship, it was verified, in average, that funds with higher proportion of return variance explained by the presence of noise traders is likely to have higher observed weekly standardised discounts/premiums change variance. But this positive correlation is not statistically significant and the determination coefficient $\left(\mathrm{R}_{2}=1.65 \%\right)$ is not very high. However, our results do not diverge from those achieved by Brauer (1993). His coefficients are not significantly positive, as well. Even so, his coefficient of determination is slightly superior - around 5\%. We believe that these results match with the relative low relevance of the investor sentiment theory, in quantitative terms, on the explanation of the variability of the discounts/premiums as they demonstrate such a low explanatory power.

The results of these linear regressions corroborate those previously achieved. subsequently, the proportion of the weekly discounts/premiums change variance as explained by the presence of noise traders is small, so the investor sentiment theory, although can have some explanatory power in relation to both the persistence and existence of the closed-end funds discounts/premiums (our study confirmed the regularity of some of its implications as predicted by the theory), it scarcely can explain a small part of this "puzzle".

\section{CONCLUSIONS AND SUGGESTIONS FOR FUTURE RESEARCH.}

This research is based on the investor sentiment theory as conceptual framework to explain the existence and persistence of the discounts/premiums, because we believe it to be the most extensive one, i.e., which theoretically explains the facts "sui generis" related to the behaviour of the closed-end funds discounts/premiums, explaining not only the persistence of the discounts/premiums, but also, the reason for, at certain times, funds being traded at premium.

Moreover we tested some implications of this theory regarding discounts/premiums behaviour (its correlation, stacionarity and if they contain information about the fund future return and/or its NAV returns). We tried to confirm, as well, if this theory is relevant to the explanation of the discounts/premiums variability (there is little research on this). Most of the research papers published till the moment were only focused on finding empirical evidence concerning the investor sentiment theory in the explanation of the discounts/premiums existence and persistence, testing some implications of De Long, Shleifer, Summers \& Waldmann model (1990) in the discounts/premiums behaviour. Only Brauer (1993) tried to measure its relevance. Still to be pointed out to test the discounts/premiums predictive

\footnotetext{
${ }^{35}$ If the ratio between the estimated variance and the observed variance of weekly standardised discounts/premiums change variance is exactly $8.55 \%$ to all the funds, the regression slope would be the inverse, that is to say, 11.696 with t-statistical infinite and the determination coefficient would be equal to one.
} 
power we have used panel data analysis, which still have not been applied by the published researches up to the moment, as best of our knowledge.

The results presented in the previous sections allow us to confirm some of the investor sentiment theory underlying implications concerning to the discounts/premiums behaviour, requiring that noise traders are present in the closed-end funds market. However, when we analyse the relevance of this theory to the explanation of the weekly standardised discounts/premiums change variance, we verify that the investor sentiment theory can only explain $8.6 \%$ of that variance. This result is confirmed by the panel data analysis. We have analysed the linear correlation between the observed weekly standardised discounts/premiums change variance and the estimated variance as well as between the observed variance and the proportion of the fund return variance explained by the noise trading. Like Brauer's (1993) study, we do not find empirical evidence that allows us to announce, definitely, that investor sentiment theory explains great part of the discounts/premiums variance (regardless of our results being slightly more optimistic).

Though, this research presents as main limitation the fact of using a methodology, so-called indirect, to determine the influence of the noise traders in the discounts/premiums variance, which is based on the ratio of the implied to observed fund return variance as indicator of the investor sentiment, resulting from this, as it is evident, deviations in relation to what would be expected. The fact that the results were not very satisfactory regarding what would be expected might have to do with the limitation of the applied methodology, ${ }^{36}$ even though we found some evidence that noise traders are present in this market. These results also imply that there must be other factors that joint with the one now analysed will better explain this puzzle. One of those factors may be related with limits of arbitrage and the performance of the arbitrageurs. Shleifer and Vishny (1997) postulate that there are limitations to the arbitrage (such as, transaction costs, financial restrictions, agency costs, among other) that difficult the arbitrageurs activity. This inhibits them of implementing perfect strategies and, as a consequence, the quick adjustment of the market prices is not verified. Such limits might allow that the irrational investors affect fund prices for more time than desired. As the discounts/premiums persist, it would be interesting to study why the arbitrageurs are notable to implement with total success its strategies as well as if they are really present in the closed-end funds market. It would still be important to study if there is a relationship between the arbitrageurs "impotence" in leading to converge the fund prices to NAV (that may be one of the reasons of the closed-end funds discounts/premiums persistence) and the investor sentiment.

Also to be noticed that the studies that, up to the moment, were disclosed concentrate the attention in a restricted group of factors, studying them a lot of times in an isolated way, and they rarely make the study with the combination of several and different factors, above all the factors of rational nature with non rational ones - said behavioural factors. Future developments might try to find methodologies that combine these two factor types, namely the investor sentiment theory and the limits of arbitrage, as explanation of the discounts/premiums. Another investigation path will be to analyse the investor sentiment comparing to the investors' appetence ${ }^{37}$ for open-end investment funds (potentials competitors of the closed-end funds) with the time that new funds are

\footnotetext{
${ }^{36}$ No one can deny, taking into consideration the results obtained in the present study and in other researches (v.g.: Neal \& Wheatley, 1998; Elton, Gruber \& Busse, 1998; Frankel \& Schmukler, 1996; Hardouvelis, La Carries \& Wizman, 1993; Brauer, 1993; Chen, Kan \& Miller, 1993; Chopra, Lee \& Shleifer,1993; Lee, Shleifer \& Thaler, 1991; Lee, Shleifer \& Thaler, 1990, among others) that noise traders are in the market and they influence it, increasing prices volatility (v.g.: Brown, 1999).

${ }^{37}$ The investors' appetence for open-end funds (the demand for open-end funds) may be measured by the liquid acquisition of participation units - the difference between the number of acquired units and redeemed units.
} 
placed on the market, and the evolution of the seasoned one (namely the behaviour of its discounts/premiums) since it has been verified that new funds, that try to offer different investment policy (objectives) from the seasoned one, appeared when the other closedend funds were at premium or at reduced discount.

\section{BIBLIOGRAPHICAL REFERENCES.}

Abraham, Abraham; Elan, Don; Marcus, Alan J.; 1993; "Does Sentiment Explain Closed-end Fund Discounts? Evidence From Bond Funds"; Financial Review; 28(4); November 1993; pp. 607-616.

Arak, Marcelle; Taylor, Dean; 1996a; "Optimal Trading With Mean-Reverting Prices: Switching Between Foreign Stocks and Closed-end Country Funds"; Applied Economics; 28(9); September 1996; pp. 1067-1074.

Arak, Marcelle; Taylor, Dean; 1996b; "Risk and Return in Trading Closed - End Country Funds: Can Trading Beat Holding Foreign Stocks?"; The Quarterly Review of Economics and Finance; 36(2); Summer 1996; pp. 219-231

Arellano, Manuel; 1993; "On the Testing of Correlated Effects with Panel Data"; Journal of Econometrics; 59; pp. 87-97.

Baltagi, Badi H.; 1995; Econometric Analysis of Panel Data; John Wiley \& Sons, Chichester, 1995.

Barclay, Michael J.; Holderness, Clifford G.; Pontiff, Jeffrey; 1993; "Private Benefits from Block Ownership and Discounts on Closed-end Funds"; Journal of Financial Economics; 33; pp. 263-291.

Bonser-Neal, Catherine; Brauer, Greggory; Neal Robert; Wheatley, Simon; 1990; "International Investment Restrictions and Closed-end Country Fund Prices"; The Journal of Finance; 45(2); June 1990; pp. 523-547.

Bordurtha, J. N.; Kim, D.; Lee, Charles M. C.; 1995; "Closed-end Country Funds and U.S. Market Sentiment"; Review of Financial Studies; 8; pp. 879-918.

Brauer, Greggory A.; 1984;"Open-ending Closed-end Funds"; Journal of Financial Economics; 13; pp. 491-507.

Brauer, Greggory A.; 1988; "Closed-end Fund Shares' Abnormal Returns and the Information Content of Discounts and Premiums"; The Journal of Finance; 43(1); March 1988; pp. 113-127

Brauer, Greggory A; 1993; "Investor Sentiment and the Closed-end Fund Puzzle: a 7 Percent Solution"; Journal of Financial Services Research; 7(3); September 1993; pp. 199-216.

Brickley, A. James; Schallheim, James S.; 1985; "Lifting the Lid on Closed-end Investment Companies: A Case of Abnormal Returns"; Journal of Financial and Quantitative Analysis; 20(1); March 1985; pp. 107-117.

Brown, Gregory W.; 1999; "Volatility, Sentiment, and Noise Traders"; Financial Analysts Journal; 55 (2); March/April 1999; pp. 82-90.

Chen, Nai-Fu; Kan, Raymond; Miller, Merton H.; 1993; "Are the Discounts on Closed-end Funds a Sentiment Index?"; The Journal of Finance; 48(2); June 1993; pp. 795-800.

Cheng, A.; Copeland, L.; O'Hanlon, J.; 1994; "Investments Trust Discounts and Abnormal Returns: UK Evidence"; Journal of Business Finance \& Accounting; 21(6); September 1994; pp. 813-831.

Cheung, C. Sherman; Kwan, Clarence C. Y.; Lee, Jason; 1997; "The Noise Trader Hypothesis: The Case of Closed - End Country Funds"; Reserch in Finance (Edited by Andrew H. Chen) vol. 15; pp. 115-136.

Chopra, Navin; Lee, Charles M.C.; Shleifer, Andrei; Thaler, Richard H.; 1993; "Yes, Discounts on Closed-end Funds Are a Sentiment Index"; The Journal of Finance; 48(2); June 1993; pp. 801-808.

De Long, Bradford; Shleifer, Andrei; Summers, Lawrence; Waldmann, Robert; 1990; "Noise Trader Risk in Financial Markets"; Journal of Political Economy; 98; August 1990, pp. 703-738

De Long, J. Bradford; Shleifer, Andrei; 1992; "Closed-end Fund Discounts"; The Journal of Portfolio Management; Winter 1992; pp. 46-53. 
Dimson, Elroy; Minio-Koserski, Carolina; 1998; "Closed-end Funds: A Survey"; LBS, forthcoming in Financial Markets, Institutions \& Instruments; September 1998; p. 79.

EIton, Edwin J.; Gruber, Martin J.; Busse, Jeffrey A.; 1998; "Do Investors Care About Sentiment"; The Journal of Business; 71(4); October 1998; pp. 477-500.

Frankel, Jeffrey A.; Schmukler, Sergio L.; 1996; "Country Fund Discounts, Asymmetric Information and the Mexican Crisis of 1994: Did Local Residents Turn Pessimistic before International Investors?"; NBER Working Paper no 5714; August 1996; pp. 43.

French, Kenneth; Roll, Richard; 1986; "Stock Return Variances - The Arrival of Information and Reaction of Traders"; Journal of Financial Economics; 17;North-Holland; 1986; pp. 5-26.

Hardouvelis, Gikas A.; La Porta, Rafael; Wizman, Thierry A.; 1993; "What Moves the Discounts on Country Equity Funds?"; NBER Working Paper no 4571; December 1993; p. 76

Hausman, J. A.; 1978; "Specification Tests in Econometrics"; Econometrica; 46(6); November 1978; pp. 1251-1271.

Hausman, Jerry A.; Taylor, William E.; 1981; "Panel data and Unobservable Individual Effects"; Econometrica; 49(6); November 1981; pp. 1377-1398.

Holly, Alberto; 1982; “A Remark on Hausman's Specification Test”; Econometrica; 50(3); May 1982; pp. 749-759.

Hsiao, Cheng; 1986; Analysis of Panel Data; Econometric Society Monographs No. 11; Cambridge University Press, Cambridge, 1986.

Jorge, Susana M. Faustino; 1997; Determinantes da Estrutura de Capitais: um Caso Português - 1990 a 1995; Dissertação de Mestrado; Escola de Economia e Gestão da Universidade do Minho; Braga, 1997.

Klibanoff, Peter; Lamont, Owen; Wizman, Thierry; 1998; "Investor Reaction to Salient News in Closed-end Country Funds"; The Journal of Finance; 35(2); April 1998; pp. 673-699.

Kramer, Charles; Smith, R. Todd; 1995; "Recent Turmoil in Emerging Markets and The Behavior of Country-Fund Discounts: Renewing The Puzzle of Pricing of Closed-End Mutual Funds"; IMF Working Paper, WP/95/68; July 1996; p. 26.

Lee, Charles M. C.; Shleifer, Andrei; Thaler, Richard H.; 1990; "Closed-end Mutual Funds"; Journal of Economic Perspectives; 4(4); Fall 1990; pp. 153-164.

Lee, Charles M. C.; Shleifer, Andrei; Thaler, Richard H.; 1991; "Investor Sentiment and the Closed-end Fund Puzzle"; The Journal of Finance; 46(1); March 1991; pp. 75-109.

Levis, Mario; Thomas, Dylan C.; 1995; "Investments Trust IPO's: Issuing Behavior and Price Performance Evidence From London Stock Exchange"; Journal of Banking \& Finance; 19(8); November 1995; pp. 1437-1458.

Monte, Ana Paula Carvalho; 2000; Sobre os Discounts/Premiums dos Fundos de Investimento Fechados no Contexto da Teoria do Sentimento do Investidor.; Dissertação de Mestrado; Escola de Economia e Gestão da Universidade do Minho; Braga, 2000.

Monte, Ana Paula Carvalho e Armada, M. J. da Rocha; 2000; Sobre os Discounts/Premiums dos Fundos de Investimento Fechados: uma digressão sobre os quadros conceptuais que explicam a sua existência.; Working paper no 7/2000; Núcleo de estudos em Gestão; Universidade do Minho; Braga, Novembro 2000 .

Newey, Whitney K.; West, Kenneth D.; 1987; “A Simple, Positive Semi-Definite, Heteroskedasticity and Autocorrelation Consistent Covariance Matrix"; Econometrica; 55(3); May 1987; pp. 703-708.

Peavy, J.; 1990; "Returns on Initial Public Offerings of Closed-end Funds"; Review of Financial Studies; 3; pp. 695-708.

Pindyck, Robert S.; Rubinfeld, Daniel L.; 1998; Econometric Models and Economic Forecasts; 4th Edition, Economic Series, McGraw-Hill International Editions, 1998.

Pontiff, Jeffrey; 1995; "Closed-end Premia and Returns Implications for Financial Market Equilibrium"; Journal of Financial Economics; 37; pp. 341-370. 
Shleifer, Andrei; Summers, Lawrence H.; 1990; "The Noise Trader Approach to Finance"; Journal of Economic Perspectives; 4(2), Spring 1990; pp. 19-33.

Shleifer, Andrei; Vishny, Robert W.; 1997; "Limits of Arbitrage"; Journal of Finance; 52, pp. 33-55.

Sias, Richard W.; 1997a; "Price Pressure and the Role of Institutional Investors in Closed-end Funds"; The Journal of Financial Research; 20(2); Summer 1997; pp. 211-229.

Sias, Richard W.; 1997b; "The Sensitivity of Individual and Institutional Investors Expectations To Changing Market Conditions: Evidence from Closed-End Funds"; Review of Quantitative Finance and Accounting; 8; 1997; pp. 245-269.

Stwart, Jon; Gill, Len; 1998; Econometrics; 2th Edition, Prentice Hall Europe, Oxford, 1998.

Weiss, Kathleen; 1989; "The Post-Offering Price Performance of Closed-end Funds"; Financial Management; Autumn 1989; pp. 57-65.

White, Halbert; 1980; “A Heteroskedasticity-Consistent Covariance Matrix Estimator and a Direct Test for Heteroskedasticity”; Econometrica; 48(4); May 1980; pp. 817-838. 
APPENDIX

Table 1 - Funds contained in the sample.

\begin{tabular}{|c|c|c|c|c|}
\hline Fund Name & TICKER & IPO Date & Sample Period & No. Obs. \\
\hline Adams Express Company & ADX & $01 / 10 / 29$ & $2.01 .1987 \mathrm{a} 18.06 .1999$ & 650 \\
\hline Allmerica Securities Trust & ALM & $28 / 02 / 73$ & 2.01 .1987 a 18.06 .1999 & 650 \\
\hline ACM Managed Income Fund & AMF & $03 / 10 / 88$ & $4.11 .1988 \mathrm{a} 18.06 .1999$ & 531 \\
\hline Bergstrom Capital Corporation & BEM & $25 / 04 / 68$ & 2.01 .1987 a 18.06 .1999 & 650 \\
\hline Baker Fentress \& Company & BKF & $01 / 01 / 71$ & 2.01 .1987 a 18.06 .1999 & 650 \\
\hline BlackRock Income Trust & BKT & $29 / 07 / 88$ & 5.08.1988a 18.06.1999 & 543 \\
\hline Blue Chip Value Fund & BLU & $02 / 04 / 87$ & 1.05 .1987 a 18.06 .1999 & 609 \\
\hline Central Securities & CET & $01 / 10 / 29$ & 2.01 .1987 a 18.06 .1999 & 650 \\
\hline CIM High Yield Securities & CIM & $18 / 11 / 87$ & $4.12 .1987 \mathrm{a} 18.06 .1999$ & 580 \\
\hline Clemente Global Growth Fund & CLM & $01 / 07 / 87$ & $31.07 .1987 \mathrm{a} 8.06 .1999$ & 596 \\
\hline CNA Income Shares & $\mathrm{CNN}$ & $15 / 05 / 73$ & 2.01 .1987 a 18.06 .1999 & 650 \\
\hline Counsellors Tandem Securities Fund & CTF & $01 / 10 / 86$ & $2.01 .1987 \mathrm{a} 15.11 .1996$ & 641 \\
\hline Duff \& Phelps Utilities Income & DNP & $28 / 01 / 87$ & $6.02 .1987 \mathrm{a} 18.06 .1999$ & 621 \\
\hline Engex & EGX & $20 / 11 / 68$ & 2.10 .1987 a 18.06 .1999 & 612 \\
\hline Excelsior Income Shares & EIS & $30 / 05 / 73$ & 2.01 .1987 a 18.06 .1999 & 651 \\
\hline Franklin Universal Trust & FT & $23 / 09 / 88$ & $30.09 .1988 \mathrm{a} 8.06 .1999$ & 534 \\
\hline Gabelli Equity Trust & GAB & $14 / 08 / 86$ & 2.01 .1987 a 18.06 .1999 & 650 \\
\hline General American Investors & GAM & $30 / 01 / 27$ & 2.01 .1987 a 18.06 .1999 & 650 \\
\hline Templeton Global Income Fd & GIM & $24 / 03 / 88$ & 1.04 .1988 a 18.06 .1999 & 561 \\
\hline CIGNA High Income Shares & HIS & $10 / 08 / 88$ & 2.09 .1988 a 18.06 .1999 & 539 \\
\hline Hampton Utilities Trust & $\mathrm{HU}$ & $08 / 03 / 88$ & 1.04 .1988 a 5.08 .1994 & 307 \\
\hline Morg Stan D Witter Income Sec & ICB & $06 / 04 / 73$ & 2.01 .1987 a 18.06 .1999 & 650 \\
\hline CIGNA Investment Securities & IIS & $24 / 01 / 73$ & 2.01 .1987 a 18.06 .1999 & 650 \\
\hline John Hancock Investors Trust & $\mathrm{JHI}$ & $29 / 01 / 71$ & 2.01 .1987 a 18.06 .1999 & 650 \\
\hline Scudder Global High Income Fund & LBF & $31 / 07 / 92$ & 31.07 .1992 a 8.06 .1999 & 335 \\
\hline Mentor Income Fund & MRF & $30 / 12 / 88$ & 6.01 .1989 a 18.06 .1999 & 521 \\
\hline Putnam Dividend Income Fund & PDI & $21 / 09 / 89$ & 6.01 .1989 a 18.06 .1999 & 482 \\
\hline Petroleum and Resources Corp. & PEO & $30 / 01 / 29$ & 2.01 .1987 a 18.06 .1999 & 650 \\
\hline Pacholder Fund & PHF & $23 / 11 / 88$ & 2.012 .1988 a 8.06 .1999 & 526 \\
\hline Putnam Master Income Trust & PMT & $28 / 12 / 87$ & 1.01 .1988 a 18.06 .1999 & 574 \\
\hline Pilgrim Prime Rate Trust & PPR & $12 / 05 / 88$ & 3.04 .1992 a 18.06 .1999 & 377 \\
\hline Cohen \& Steers Realty Income Fund & RIF & $23 / 08 / 88$ & 20.09 .1988 a 8.06 .1999 & 539 \\
\hline Salomon Brothers Fund & SBF & $24 / 09 / 29$ & 2.01 .1987 a 18.06 .1999 & 650 \\
\hline Source Capital & SOR & $24 / 10 / 68$ & 2.01 .1987 a 8.06 .1999 & 650 \\
\hline Tuxis Corporation & TUX & $08 / 11 / 96$ & 6.12 .1996 a 25.12 .1998 & 83 \\
\hline Tri-Continental Corporation & TY & $31 / 12 / 29$ & 2.01 .1987 a 18.06 .1999 & 650 \\
\hline Liberty All-Star Equity Fund & USA & $24 / 10 / 86$ & 2.01 .1987 a 18.06 .1999 & 638 \\
\hline Vestaur Securities & VES & $30 / 11 / 72$ & 2.01 .1987 a 18.06 .1999 & 650 \\
\hline Van Kampen Income Trust & VIN & $21 / 04 / 88$ & 20.03 .1987 a 8.06 .1999 & 556 \\
\hline Zweig Fund & $\mathrm{ZF}$ & $03 / 10 / 86$ & 2.01 .1987 a 18.06 .1999 & 640 \\
\hline Zenix Income Fund & ZIF & $27 / 04 / 88$ & 6.05 .1988 a 18.06 .1999 & 556 \\
\hline Zweig Total Return Fund & ZTR & $22 / 09 / 88$ & 4.11 .1988 a 18.06 .1999 & 530 \\
\hline
\end{tabular}

Table 2 - Characterisation of the sample to the "Fund Discount/premium" variable, during the period $2 / 01 / 1987$ to $18 / 06 / 1999$

\begin{tabular}{|c|r|r|r|r|r|c|}
\hline Year & mean & \multicolumn{1}{|c|}{ stdev } & max & min & $\mathbf{n}^{\mathbf{o}}$ obs. & $\mathbf{n}^{\mathbf{o}}$ of funds \\
\hline 1987 & -5.98 & 9.63 & 17.25 & -43.82 & 1048 & 23 \\
1988 & -8.45 & 10.40 & 14.75 & -35.95 & 1374 & 30 \\
1989 & -6.51 & 10.04 & 17.92 & -32.82 & 1855 & 38 \\
1990 & -7.09 & 9.08 & 20.52 & -28.29 & 2005 & 39 \\
1991 & -4.02 & 8.78 & 28.21 & -30.42 & 2026 & 39 \\
1992 & 0.44 & 9.62 & 29.32 & -27.91 & 2062 & 40 \\
1993 & -0.24 & 9.38 & 32.40 & -26.58 & 2121 & 41 \\
1994 & -3.49 & 9.99 & 22.02 & -31.73 & 2087 & 41 \\
1995 & -6.22 & 9.36 & 18.10 & -31.97 & 2080 & 40 \\
1996 & -6.57 & 9.28 & 16.08 & -31.02 & 2074 & 40 \\
1997 & -5.31 & 9.87 & 23.63 & -34.05 & 2028 & 39 \\
1998 & -3.60 & 9.39 & 52.44 & -28.50 & 2028 & 39 \\
1999 & -5.10 & 10.02 & 28.16 & -27.48 & 975 & 39 \\
\hline total & -4.58 & 9.90 & 52.44 & -43.82 & 23763 & 41 \\
\hline
\end{tabular}


Table 3 - Correlation between weekly discount/premium level (in \%) of the closed-end funds.

\begin{tabular}{|c|ccc|}
\hline \multirow{4}{*}{ Weekly } & \multicolumn{3}{|c|}{ Pearson Correlation Coefficient } \\
\cline { 2 - 4 } Discounts/premiums & mean & Maximum & Minimum \\
\cline { 2 - 4 } & 0.188 & 0.878 & -0.767 \\
\cline { 2 - 4 } & \multicolumn{3}{|c|}{ Frequency of the coefficient signal } \\
\cline { 2 - 4 } & Positive & Negative & Total \\
& 583 & 237 & 820 \\
& $(514)$ & $(181)$ & $(695)$ \\
\hline
\end{tabular}

Note: The values in parenthesis correspond to the number of Pearson correlation coefficients significant for a level of 5\% (bilateral).

Table 4 - Synthesis of the tests results of the unit root tests in the discount/premium variable of the closed-end investment funds.

\begin{tabular}{|c|c|c|c|c|c|c|c|}
\hline \multirow{2}{*}{ Test } & \multirow{2}{*}{ N.S. ${ }^{1}$} & \multicolumn{4}{|c|}{$\mathrm{N}^{0}$ of funds that } & \multirow{2}{*}{$\mathbf{E T}^{2}$} & \multirow{2}{*}{ p-value } \\
\hline & & \multicolumn{2}{|c|}{ Reject Ho } & \multicolumn{2}{|c|}{ Do not reject Ho } & & \\
\hline \multirow{3}{*}{ ADF } & $1 \%$ & 10 & $(24 \%)$ & 31 & $(76 \%)$ & 3.2796 & $(0.0005)$ \\
\hline & $5 \%$ & 14 & $(34 \%)$ & 27 & $(66 \%)$ & 2.0303 & $(0.0212)$ \\
\hline & $10 \%$ & 21 & $(51 \%)$ & 20 & $(49 \%)$ & -0.1562 & $(0.5621)$ \\
\hline \multirow{3}{*}{$\mathbf{P P}$} & $1 \%$ & 19 & $(46 \%)$ & 22 & $(54 \%)$ & -0.4685 & $(0.3197)$ \\
\hline & $5 \%$ & 26 & $(63 \%)$ & 15 & $(37 \%)$ & 1.7179 & $(0.0429)$ \\
\hline & $10 \%$ & 32 & $(78 \%)$ & 9 & $(22 \%)$ & 3.5920 & $(0.0002)$ \\
\hline
\end{tabular}

Table 5 - Statistics - summary of the predictive power of the discounts/premiums on the fund return (accumulated).

\begin{tabular}{|c|c|c|c|c|c|c|c|c|c|c|c|c|c|}
\hline \multirow{2}{*}{\multicolumn{2}{|c|}{$N^{o}$ of funds with }} & \multicolumn{4}{|c|}{$\mathbf{N}=1$} & \multicolumn{4}{|c|}{$N=4$} & \multicolumn{4}{|c|}{$N=13$} \\
\hline & & Freq. & $\%$ & ET $^{1}$ & p-value & Freq. & $\%$ & $\mathrm{ET}^{1}$ & p-value & Freq. & $\%$ & ET $^{1}$ & p-value \\
\hline \multicolumn{2}{|l|}{$\beta_{i}>0$} & 40 & $97.6 \%$ & 13.9944 & 0.00000 & 35 & $85.4 \%$ & 11.7002 & 0.00000 & 33 & $80.5 \%$ & 10.7825 & 0.00000 \\
\hline \multicolumn{2}{|l|}{$\beta_{i} \leq 0$} & 1 & $2.4 \%$ & -3.9001 & 0.99995 & 6 & $14.6 \%$ & -1.6059 & 0.94585 & 8 & $19.5 \%$ & -0.6882 & 0.75435 \\
\hline \multirow{3}{*}{$\begin{array}{c}\quad \beta_{i} \\
\text { significant }\end{array}$} & $10 \%{ }^{2}$ & 29 & $72.5 \%$ & 8.9472 & 0.00000 & 22 & $55.0 \%$ & 5.7354 & 0.00000 & 26 & $65.0 \%$ & 7.5707 & 0.00000 \\
\hline & $5 \%$ & 26 & $65.0 \%$ & 7.5707 & 0.00000 & 16 & $40.0 \%$ & 2.9824 & 0.00143 & 23 & $57.5 \%$ & 6.1942 & 0.00000 \\
\hline & $1 \%$ & 19 & $47.5 \%$ & 4.3589 & 0.00001 & 7 & $17.5 \%$ & -1.1471 & 0.87433 & 14 & $35.0 \%$ & 2.0647 & 0.01947 \\
\hline \multirow{3}{*}{$\begin{array}{l}\beta_{i}>0 \\
\text { and } \\
\text { significant }\end{array}$} & $10 \%$ & 12 & $30.0 \%$ & 1.1471 & 0.12567 & 19 & $47.5 \%$ & 4.3589 & 0.00001 & 18 & $45.0 \%$ & 3.9001 & 0.00005 \\
\hline & $5 \%$ & 15 & $37.5 \%$ & 2.5236 & 0.00581 & 24 & $60.0 \%$ & 6.6531 & 0.00000 & 21 & $52.5 \%$ & 5.2766 & 0.00000 \\
\hline & $1 \%$ & 21 & $52.5 \%$ & 5.2766 & 0.00000 & 33 & $82.5 \%$ & 10.7825 & 0.00000 & 26 & $65.0 \%$ & 7.5707 & 0.00000 \\
\hline
\end{tabular}

Notes: ${ }^{1}$ ET- test statistics: $Z$ test to the binomial proportion of a sample of great dimension and the respective test value (p-value).

Table 6 - Statistics - summary of the predictive power of the discounts/premiums on the NAV return (accumulated).

\begin{tabular}{|c|c|c|c|c|c|c|c|c|c|c|c|c|c|}
\hline \multirow{2}{*}{\multicolumn{2}{|c|}{$N^{\circ}$ of funds with }} & \multicolumn{4}{|c|}{$\mathbf{N}=1$} & \multicolumn{4}{|c|}{$N=4$} & \multicolumn{4}{|c|}{$\mathrm{N}=13$} \\
\hline & & Freq. & $\%$ & ET $^{1}$ & p-value & Freq. & $\%$ & ET $^{1}$ & p-value & Freq. & $\%$ & ET $^{1}$ & p-value \\
\hline \multicolumn{2}{|l|}{$\beta_{i}<0$} & 34 & $82.9 \%$ & 4.2167 & 0.00001 & 24 & $58.5 \%$ & 1.0932 & 0.13715 & 20 & $48.8 \%$ & -0.1562 & 0.56205 \\
\hline \multicolumn{2}{|c|}{$\beta_{i} \geq 0$} & 7 & $17.1 \%$ & -4.2167 & 0.99999 & 17 & $41.5 \%$ & -1.0932 & 0.86285 & 21 & $51.2 \%$ & 0.1562 & 0.43795 \\
\hline \multirow{3}{*}{$\begin{array}{c}\quad \beta_{i} \\
\text { significant }\end{array}$} & $10 \%^{2}$ & 18 & $43.9 \%$ & -0.7809 & 0.78256 & 7 & $17.1 \%$ & -4.2167 & 0.99999 & 14 & $34.1 \%$ & -2.0303 & 0.97883 \\
\hline & $5 \%$ & 16 & $39.0 \%$ & -1.4056 & 0.92007 & 3 & $7.3 \%$ & -5.4661 & 1.00000 & 10 & $24.4 \%$ & -3.2796 & 0.99948 \\
\hline & $1 \%$ & 13 & $31.7 \%$ & -2.3426 & 0.99043 & 1 & $2.4 \%$ & -6.0908 & 1.00000 & 2 & $4.9 \%$ & -5.7784 & 1.00000 \\
\hline \multirow{3}{*}{$\begin{array}{l}\beta_{i}<0 \\
\text { and } \\
\text { significant }\end{array}$} & $10 \%$ & 18 & $43.9 \%$ & -0.7809 & 0.78256 & 4 & $9.8 \%$ & -5.1537 & 1.00000 & 11 & $26.8 \%$ & -2.9673 & 0.99850 \\
\hline & $5 \%$ & 17 & $41.5 \%$ & -1.0932 & 0.86285 & 2 & $4.9 \%$ & -5.7784 & 1.00000 & 7 & $17.1 \%$ & -4.2167 & 0.99999 \\
\hline & $1 \%$ & 13 & $31.7 \%$ & -2.3426 & 0.99043 & 1 & $2.4 \%$ & -6.0908 & 1.00000 & 2 & $4.9 \%$ & -5.7784 & 1.00000 \\
\hline
\end{tabular}

Notes: ${ }^{1}$ ET- test statistics: $Z$ test to the binomial proportion of a sample of great dimension and the respective test value (p-value). 
Table 7 - Summary of the results of the panel data analysis - hypothesis tests.

\begin{tabular}{|c|c|c|c|}
\hline & & $\mathbf{A}$ & B \\
\hline \multicolumn{4}{|c|}{$H_{1}: \alpha_{1}=\alpha_{2}=\ldots . .=\alpha_{N} \wedge \beta_{1}=\beta_{2}=\ldots \ldots=\beta_{N}$} \\
\hline$K=1$ & $\begin{array}{l}\boldsymbol{F}_{\boldsymbol{I}} \\
(p \text { value })\end{array}$ & $\begin{array}{r}127.92 \\
(0.00) \\
\end{array}$ & $\begin{array}{r}117.03 \\
(0.00) \\
\end{array}$ \\
\hline$K=4$ & $\begin{array}{l}\boldsymbol{F}_{\boldsymbol{I}} \\
\left(p \_ \text {value }\right)\end{array}$ & $\begin{array}{r}\mathbf{1 2 5 . 5 2} \\
(0.00)\end{array}$ & $\begin{array}{r}111.96 \\
(0.00)\end{array}$ \\
\hline$K=13$ & $\begin{array}{l}\boldsymbol{F}_{\boldsymbol{I}} \\
(p \text { value })\end{array}$ & $\begin{array}{r}119.60 \\
(0.00) \\
\end{array}$ & $\begin{array}{r}\mathbf{7 5 . 2 2} \\
(0.00) \\
\end{array}$ \\
\hline \multicolumn{4}{|c|}{$H_{2}: \alpha_{1} \neq \alpha_{2} \neq \ldots \ldots \neq \alpha_{N} \quad \wedge \quad \beta_{1}=\beta_{2}=\ldots \ldots=\beta_{N}}$. \\
\hline$K=1$ & $\begin{array}{l}\boldsymbol{F}_{2} \\
(p \text { value })\end{array}$ & -2.20 & -1.34 \\
\hline$K=4$ & $\begin{array}{l}\boldsymbol{F}_{2} \\
(p \text { value })\end{array}$ & -2.30 & -3.22 \\
\hline$K=13$ & $\begin{array}{l}\boldsymbol{F}_{2} \\
(p \text { value })\end{array}$ & -4.32 & -6.04 \\
\hline \multicolumn{4}{|c|}{$H_{3}: \alpha_{1}=\alpha_{2}=\ldots .=\alpha_{N} \quad$ dado $\quad \beta_{1}=\beta_{2}=\ldots \ldots=\beta_{N}$. } \\
\hline$K=1$ & $\begin{array}{l}\boldsymbol{F}_{3} \\
(p \text { value })\end{array}$ & $\begin{array}{r}\mathbf{2 6 0 . 3 4} \\
(0.00) \\
\end{array}$ & $\begin{array}{r}236.88 \\
(0.00) \\
\end{array}$ \\
\hline$K=4$ & $\begin{array}{l}\boldsymbol{F}_{3} \\
(p \text { value })\end{array}$ & $\begin{array}{r}\mathbf{2 5 5 . 6 9} \\
(0.00) \\
\end{array}$ & $\begin{array}{r}229.75 \\
(0.00) \\
\end{array}$ \\
\hline$K=13$ & $\begin{array}{l}\boldsymbol{F}_{3} \\
(p \text { value })\end{array}$ & $\begin{array}{r}247.26 \\
(0.00)\end{array}$ & $\begin{array}{r}\mathbf{1 5 9 . 6 0} \\
(0.00)\end{array}$ \\
\hline
\end{tabular}

Being the test statistics given by:

$$
\begin{aligned}
& F_{1}=\frac{\left(S S R_{M S}-S S R_{M C}\right) /(N-1)(M+1)}{S S R_{M C} / N T-N(M+1)} \\
& F_{2}=\frac{\left(S S R_{M I}-S S R_{M C}\right) / M(N-1)}{S S R_{M C} / N T-N(M+1)} \\
& F_{3}=\frac{\left(S S R_{M S}-S S R_{M I}\right) /(N-1)}{S S R_{M I} /(N T-N-M)}
\end{aligned}
$$

where:

$S S R_{M C} \equiv$ Residual sum of squares of the covariance model;

$S S R_{M S} \equiv$ Residual sum of squares of the simple model;

$S S R_{M S} \equiv$ Residual sum of squares of the intra-individuals model

$N \equiv$ number of funds in the sample;

$M \equiv$ number of the explanatory variables;

\begin{tabular}{|c|c|c|}
\hline & About fund return & About NAV return \\
\hline$K=1$ & $\begin{array}{l}\sum_{k=1}^{K} \operatorname{RFND}_{i, t-k}=\alpha_{i}^{f}+0.0299 \operatorname{DISC}_{i, t} \\
R_{a}^{2}=0.0069\end{array}$ & $\begin{array}{lc}\sum_{k=1}^{K} R_{i, t-k}=\alpha_{i}^{v}-0.0178 & \text { DISC }_{i, t} \\
R_{a}^{2}=0.0063 & {[0.0000]}\end{array}$ \\
\hline$K=4$ & $\begin{array}{ll}\sum_{k=1}^{K} R D_{i, t-k}=\alpha_{i}+ & 0.0378 \text { DISC }_{i, t} \\
R_{a}^{2}=0.0053 & (4.7902) \\
& \lceil 0.0000\rceil\end{array}$ & $\begin{array}{l}\sum_{k=1}^{K} R_{i, t-k}=\alpha_{i}^{v}-0.0274 L_{i, t} \text { DISC }_{i, t} \\
R_{a}^{2}=0.0120 \quad(-4.1217) \\
{[0.0000]}\end{array}$ \\
\hline$K=13$ & $\begin{array}{l}\sum_{k=1}^{K} R F N D_{i, t-k}=\alpha_{i}^{f}+0.0581 D I S C_{i, t} \\
R_{a}^{2}=0.0108\end{array}$ & $\begin{array}{lc}\sum_{k=1}^{K} R V P L_{i, t-k}=\alpha_{i}^{v}-010 \cap 4 & D I S C_{i, t} \\
R_{a}^{2}=0.0280 & (-7.5505) \\
& {[0.0000]}\end{array}$ \\
\hline
\end{tabular}

$N T \equiv$ number of panel totals observations.

Table 8 - Fixed effects Model (homogeneity of the slope and heterogeneity of the interception).

Note: $\alpha_{i}^{f}$ e $\alpha_{i}^{v}$, represents the interception coefficient of the model, is variable from fund to fund. The value among curved parenthesis corresponds to the t-statistical of the coefficient and the right parenthesis to its p-value.

Table 9 - hypotheses Tests- covariance analysis.

\begin{tabular}{|ccc|}
\hline & 1st Regression: & 2nd Regression: \\
H1: Total homogeneity of the coefficients & \\
F1 & $\mathbf{3 . 0 5 8 8 2}$ & $\mathbf{2 . 1 6 7 6 1}$ \\
p-value & 0.001471 & 0.000473 \\
H2: Slope homogeneity and interception & heterogeneity \\
F2 & $\mathbf{1 . 3 2}$ & $\mathbf{1 . 3 0}$ \\
p-value & 0.22367 & 0.128579 \\
H3: Interception homogeneity given the slope homogeneity \\
F3 & $\mathbf{1 . 8 2}$ & $\mathbf{1 . 1 4}$ \\
-value & 0.035432 & 0.312345 \\
\hline
\end{tabular}

Where:

1st Regression:

$\mathrm{r}\left(\Delta \tilde{D}_{t}\right)_{1, \mathrm{t}}=\phi_{0 \mathrm{i}, \mathrm{t}}+\phi_{1 \mathrm{i}, \mathrm{t}} \operatorname{vâr}\left(\Delta D_{t}\right)_{i, t}+\varepsilon_{i, t}$

2nd Regression:

$\overline{\operatorname{var}\left(\Delta \tilde{D}_{t}\right)_{\mathrm{i}, \mathrm{t}}=\varphi_{0 \mathrm{i}, \mathrm{t}}}+\varphi_{1 \mathrm{i}, \mathrm{t}}\left(1-V_{6}^{*}\right)_{i, t}+\varepsilon_{i, t}$ 
Table 10 - Linear Regressions relatives to the general models (7) e (8).

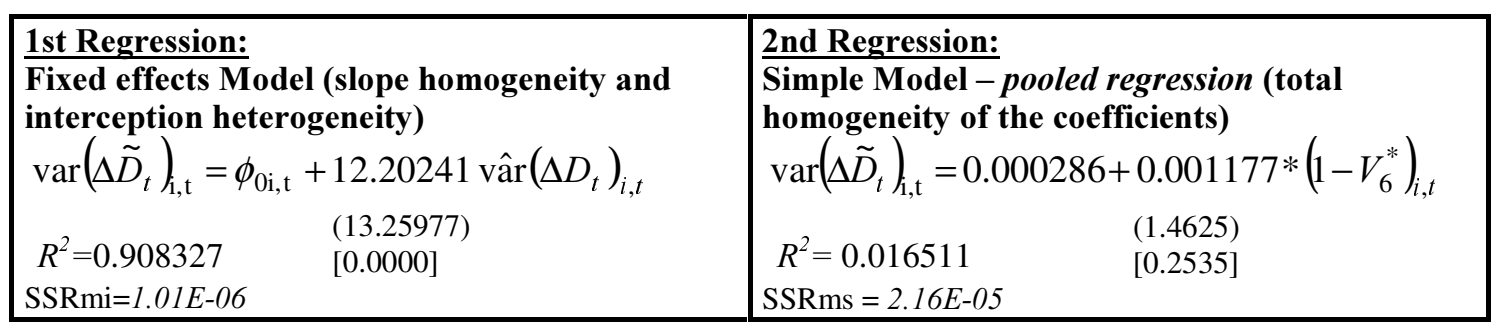

Note: $\phi_{0 i, t}$, represents the model interception coefficient, variable from fund to fund. The value among curved parenthesis corresponds to the $\mathrm{t}$-statistical of the coefficient and the right parenthesis to its p-value.

Table 11- The estimated proportion (ratio) of the estimated variance in relation to observed weekly standardised discounts/premiums change variance of the closed-end investment funds, for the period of 2/1/1987 a 31/12/1998.

\begin{tabular}{|c|c|c|c|c|}
\hline Funds & $1987-90$ & 1991-94 & $1995-98$ & $1987-98$ \\
\hline ADX & $\begin{array}{r}0.1190 \\
206\end{array}$ & $\begin{array}{r}0.0806 \\
205\end{array}$ & $\begin{array}{r}0.1754 \\
208\end{array}$ & $\begin{array}{r}0.1187 \\
619\end{array}$ \\
\hline AMF & $\begin{array}{r}0.0747 \\
88\end{array}$ & $\begin{array}{r}0.0649 \\
209\end{array}$ & $\begin{array}{r}0.0635 \\
208\end{array}$ & $\begin{array}{r}0.0675 \\
505\end{array}$ \\
\hline BEM & $\begin{array}{r}0.0714 \\
206\end{array}$ & $\begin{array}{r}0.0710 \\
209\end{array}$ & $\begin{array}{r}0.0639 \\
208\end{array}$ & $\begin{array}{r}0.0698 \\
623\end{array}$ \\
\hline BKF & $\begin{array}{r}0.1308 \\
208 \\
\end{array}$ & $\begin{array}{r}0.0679 \\
209 \\
\end{array}$ & $\begin{array}{r}0.0903 \\
208 \\
\end{array}$ & $\begin{array}{r}0.0984 \\
625 \\
\end{array}$ \\
\hline BKT & $\begin{array}{r}0.0336 \\
100\end{array}$ & $\begin{array}{r}0.0708 \\
209\end{array}$ & $\begin{array}{r}0.0694 \\
208\end{array}$ & $\begin{array}{r}0.0569 \\
517\end{array}$ \\
\hline BLU & $\begin{array}{r}0.0934 \\
164\end{array}$ & $\begin{array}{r}0.0732 \\
209\end{array}$ & $\begin{array}{r}0.0684 \\
208\end{array}$ & $\begin{array}{r}0.0798 \\
581\end{array}$ \\
\hline CLM & $\begin{array}{r}0.0775 \\
153\end{array}$ & $\begin{array}{r}0.0726 \\
207\end{array}$ & $\begin{array}{r}0.1268 \\
208\end{array}$ & $\begin{array}{r}0.0915 \\
568\end{array}$ \\
\hline DNP & $\begin{array}{r}0.0775 \\
176\end{array}$ & $\begin{array}{r}0.0842 \\
207\end{array}$ & $\begin{array}{r}0.0550 \\
208\end{array}$ & $\begin{array}{r}0.0717 \\
591\end{array}$ \\
\hline GAB & $\begin{array}{r}0.1516 \\
208\end{array}$ & $\begin{array}{r}0.0844 \\
209\end{array}$ & $\begin{array}{r}0.1005 \\
208\end{array}$ & $\begin{array}{r}0.1157 \\
625\end{array}$ \\
\hline GAM & $\begin{array}{r}0.1429 \\
208\end{array}$ & $\begin{array}{r}0.0988 \\
209\end{array}$ & $\begin{array}{r}0.1002 \\
208\end{array}$ & $\begin{array}{r}0.1225 \\
625\end{array}$ \\
\hline GIM & $\begin{array}{r}0.0715 \\
118\end{array}$ & $\begin{array}{r}0.0775 \\
205\end{array}$ & $\begin{array}{r}0.0721 \\
208\end{array}$ & $\begin{array}{r}0.0740 \\
531\end{array}$ \\
\hline HIS & $\begin{array}{r}0.0678 \\
96\end{array}$ & $\begin{array}{r}0.0783 \\
205\end{array}$ & $\begin{array}{r}0.0776 \\
208\end{array}$ & $\begin{array}{r}0.0736 \\
509\end{array}$ \\
\hline ICB & $\begin{array}{r}0.0740 \\
208\end{array}$ & $\begin{array}{r}0.0790 \\
209\end{array}$ & $\begin{array}{r}0.0715 \\
208\end{array}$ & $\begin{array}{r}0.0755 \\
625\end{array}$ \\
\hline LBF & $\begin{array}{r}0.0000 \\
0\end{array}$ & $\begin{array}{r}0.0753 \\
101\end{array}$ & $\begin{array}{r}0.0671 \\
208\end{array}$ & $\begin{array}{r}0.0683 \\
309 \\
\end{array}$ \\
\hline PDI & $\begin{array}{r}0.0605 \\
39\end{array}$ & $\begin{array}{r}0.0693 \\
209\end{array}$ & $\begin{array}{r}0.0663 \\
208\end{array}$ & $\begin{array}{r}0.0667 \\
456\end{array}$ \\
\hline PHF & $\begin{array}{r}0.0810 \\
83\end{array}$ & $\begin{array}{r}0.0531 \\
207\end{array}$ & $\begin{array}{r}0.0767 \\
208\end{array}$ & $\begin{array}{r}0.0644 \\
498\end{array}$ \\
\hline PMT & $\begin{array}{r}0.0685 \\
131 \\
\end{array}$ & $\begin{array}{r}0.0762 \\
209 \\
\end{array}$ & $\begin{array}{r}0.0821 \\
208 \\
\end{array}$ & $\begin{array}{r}0.0753 \\
548 \\
\end{array}$ \\
\hline PPR & $\begin{array}{r}0.0000 \\
0\end{array}$ & $\begin{array}{r}0.0669 \\
143\end{array}$ & $\begin{array}{r}0.0649 \\
208\end{array}$ & $\begin{array}{r}0.0657 \\
351\end{array}$ \\
\hline SBF & $\begin{array}{r}0.1410 \\
198\end{array}$ & $\begin{array}{r}0.0937 \\
207\end{array}$ & $\begin{array}{r}0.1138 \\
208\end{array}$ & $\begin{array}{r}0.1198 \\
613\end{array}$ \\
\hline SOR & $\begin{array}{r}0.0917 \\
208\end{array}$ & $\begin{array}{r}0.0730 \\
209\end{array}$ & $\begin{array}{r}0.0812 \\
208\end{array}$ & $\begin{array}{r}0.0822 \\
625\end{array}$ \\
\hline TY & $\begin{array}{r}0.0926 \\
204 \\
\end{array}$ & $\begin{array}{r}0.1075 \\
209 \\
\end{array}$ & $\begin{array}{r}0.2671 \\
208 \\
\end{array}$ & $\begin{array}{r}0.1182 \\
621 \\
\end{array}$ \\
\hline USA & $\begin{array}{r}0.1444 \\
195\end{array}$ & $\begin{array}{r}0.0728 \\
209\end{array}$ & $\begin{array}{r}0.0956 \\
208\end{array}$ & $\begin{array}{r}0.1095 \\
612\end{array}$ \\
\hline VES & $\begin{array}{r}0.0725 \\
208\end{array}$ & $\begin{array}{r}0.0797 \\
209\end{array}$ & $\begin{array}{r}0.0694 \\
208\end{array}$ & $\begin{array}{r}0.0743 \\
625\end{array}$ \\
\hline $\mathbf{Z F}$ & $\begin{array}{r}0.0851 \\
197\end{array}$ & $\begin{array}{r}0.0727 \\
209\end{array}$ & $\begin{array}{r}0.0899 \\
208\end{array}$ & $\begin{array}{r}0.0821 \\
614\end{array}$ \\
\hline ZIF & $\begin{array}{r}0.0716 \\
111 \\
\end{array}$ & $\begin{array}{r}0.0681 \\
205 \\
\end{array}$ & $\begin{array}{r}0.0720 \\
208 \\
\end{array}$ & $\begin{array}{r}0.0712 \\
524 \\
\end{array}$ \\
\hline ZTR & $\begin{array}{r}0.0677 \\
85\end{array}$ & $\begin{array}{r}0.0594 \\
207\end{array}$ & $\begin{array}{r}0.0697 \\
208\end{array}$ & $\begin{array}{r}0.0644 \\
500\end{array}$ \\
\hline $\begin{array}{c}\text { weighed } \\
\text { mean }\end{array}$ & $\begin{array}{r}\mathbf{0 . 0 9 6 5} \\
3798\end{array}$ & $\begin{array}{r}\mathbf{0 . 0 7 5 9} \\
5234\end{array}$ & $\begin{array}{r}\mathbf{0 . 0 9 0 4} \\
5408\end{array}$ & $\begin{array}{r}\mathbf{0 . 0 8 5 5} \\
14440\end{array}$ \\
\hline
\end{tabular}


